\title{
المرجعيات الثقافية القرآنية للثاعر الفارسي وحشي البافقي
}

د. جليل صاحب خليل الياسري

مديرية تربية كربلاء المقدسة

$$
\text { تاريخ القبول : 2020/11/20 : تالاستلام }
$$

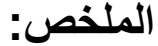

يشتغل هذا البحث على المرجعيات الثقافية القرآنية لثاعر من شعراء بلاد فارس في العصر الصفوي هو الثاعر

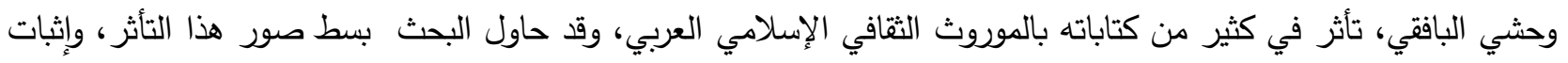

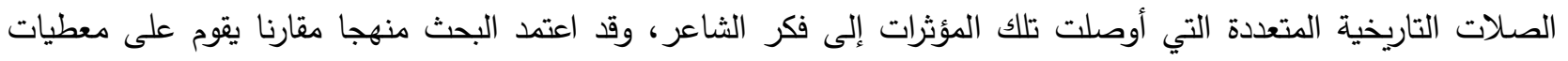

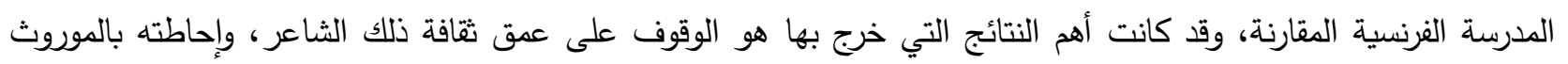

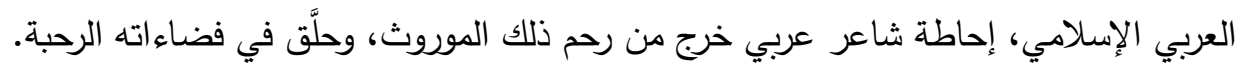

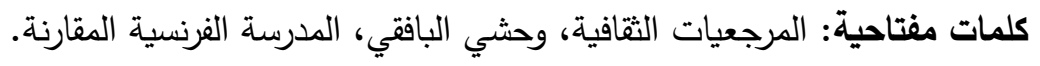




$$
\begin{aligned}
& \text { لارك للفلسفة واللساتيات والعلوم الاجتماعية/ ج2 من العد141/ سنة 2021م- (وقائع المؤتمر العلمي الاكتروني الثاني للاراسات الادبية واللنوية والنقدية المقارنة) } \\
& \text { جامعة واسط بالتعاون مع مركز الجنائن الثقافي }
\end{aligned}
$$

\title{
The Quranic cultural references of presian poet Wahshi al-Bafiq
}

\author{
Dr. Jalel Sahab Kalel Al yasiri \\ General Directorate of Education on Kerbala
}

Receipt date: $20 / 11 / 2020$

Date of acceptance: $8 / 12 / 2020$

\begin{abstract}
This research worked on the Qur'anic cultural references of a poet from Persia in the Safavid era, the poet Wahshi al-Bafiqi, who was influenced in many of his writings by the Arab Islamic cultural heritage, and the research tried to simplify the images of this influence, and prove the multiple historical links that brought those influences to The poet's thought, and the research adopted a comparative approach based on the data of the French Comparative School, and the most important results that came out with it were to find out the depth of that poet's culture, to surround him with the Arab Islamic heritage, to surround an Arab poet who emerged from the womb of that heritage, and flew in its vast spaces.
\end{abstract}

Key words: Cultural References,Wahshi al-Bafiqi,The French Comparative School 


\section{المقدمة}

فقد عانت الدراسات المقارنة من شيوع المقاربات الجمعية، لظواهر مقارنة عامة، وانحسار مساحة المقاربات القائمة على عِّنات فردية(ثخصيات أدبية)، واقتضى ذلك توجيه البوصلة البحثية إلى الثق الثاني من الدراسات، لأن أغلب مساحاتها لا زالت بكرا، لم تطأها أقلام الباحثين، من أجل الوصول إلى مصاديق عملية، لما أسست له مدارس الأدب المقارن، من المبادئ والمعايير والتصورات الخاصة بهذا الحقل المهم.

ويسعى البحث-بحدود اشتغاله- إلى تحويل مجرى العناية من الكل إلى الجزه، متخذا من الثاعر الفارسي(وحشي البافقي) عِّنة للإجراءات المقارنة، مستعينا بأداة إجرائية نقدية، لم يُلتقت إليها في الدراسات الإجرائية المقارنة -بحسب اطلاع الباحث-، وهي آلية المرجعيات الثقافية التي استعارها من حقل الخطاب النقدي الثقافي، إلى الحقل الإجرائي المقارن. وقد اشتمل البحث الموسوم (المرجعيات الثقافية القرآنية للثاعر الفارسي وحشي البافقي) على مبحثين وخاتمة، أما المبحث الأول، فقد اعتىى بالبعد التظيري الذي لا بد فيه من عرض أهم معايير المدرسة التي اشتغل البحث على وفقها، فضلا عن وجهة نظره الخاصة، فيما يخص المصطلح الإجرائي في البحث(المرجعيات الثقافية)، في حين اهتَّ المبحث الآخر بالبعد التطبيقي، وحاول جاهدا أن يتَّع طريقة إحصائية استقصت النماذج المهمة التي أحالها إلى مرجعياتها الثقافية القرآنية. وقد اعتمد البحث على ما تُرجمٍ من منظومات للشاعر ، في كتاب(من شعراء إيران الكبار وحشي البافقي)، للدكتور أحمد الخولي، نظرا لعدم توافر ترجمة لديوان الثاعر كاملا، متمنيا أن تفتح هذه المحاولة الباب لترجمة الأعمال المهمة للشعراء الفرس بعامة، و (وحشي البافقي) بخاصة، لما لها من أهمية في الدراسات التطبيقية المقارنة

ويأمل الباحث أن تكون للبحث يدُ في دد جسور التواصل بين المتلقي وبين الأدب المقارن؛ كونه حقلا معرفيا، لا يستطيع أي مهتم بالأدب اليوم غض النظر عنه، إذ أنه أضحى ركنا أساسيا من أركان المنظومة الأدبية العربية والعالمية، وتكمن فائدته في كونه يفتح للذات العربية آفاقا جديدة تطل بها على ما بين يدي الآخر من إبداعات أدبية، وتعرفها بمنزلتها بين تلك الآداب؛ لتتهض بواقعها من خلال التلاقح المفيد مستثمر الآفاق التي فتحها لها الأدب المقارن، وآخر دعوانا أن الحمد لله رب العالمين. المبحث الأول: البعد التنظيري معايير المدرسة الفرنسية المقارنة

ربما كان مصطلح الأدب المقارن مصطلحا مخادعا لأنه يجر متلقيه المبتديء إلى عالم آخر، قد يبتعد به عن ميدانه الحقيقي، ويجعل فكره ينصرف إلى عالم الموازنات القديمة، فكلمة الأدب تحمله إلى عالم الإبداع و الخيال، و المقارنة تجعل فكره 
أسير الصورة أدبين أو أديبين يقارن بينهما، لينتظر بعد ذلك أيهما يكسب قصب السبق في خلاصة المقارنة، لكن الأمر أبعد من ذللك بكثير، فالأدب المقارن بإجماع المقارنين مصطلح ضعيف الدلالة على المقصود منه، وقا رفضه كثير من الدارسين له، و اقترحوا مصطلحات مناسبة ودالة على موضو عه، و التفتو ا إلى أن إضافة كلمة تاريخ تقربه من الدقة بحسب المعطى الفرنسي

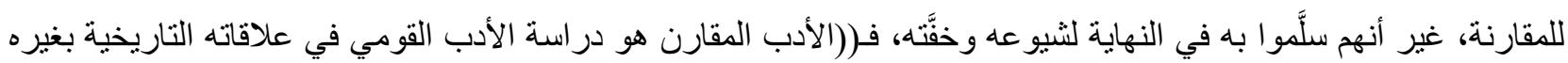

من الآداب الخارجية عن نطاق اللغة القومية التي كتب بها))( هلال، 2008م، 10) وفق معطيات المدرسة الفرنسية المقارنة. إن ريادة المدرسة الفرنسية للارس المقارن، وكون معظم رواد (الأدب المقارن) فرنسيين صبغ ذلك العلم بالطابع الفرنسي، فكان المنطلق الذي قام عليه منطلقا قوميا، نهض به أدباء فرنسيون لإثبات أصالة الأدب الفرنسي، بدعوى أنه المنهل الخصب الذي استقت منه الآداب الأوربية الأخرى، منأثرة به، صنادرة عنه، فكان معيار ها الذي لا يمكن أن تحيد عنه هو التأثير و التأثر بين الآداب، والدذاهب الأدبية، والأدباء أنفسهم، و هو العمود الفقري الذي قامت عليه الدراسات الدقارنة، و أنه الأساس الذي قامت عليه تللك المدرسة المقارنة، هذه المدرسة التي استطالت على عالم المقارنة منفردة لما بربو على قرن من الزمان،

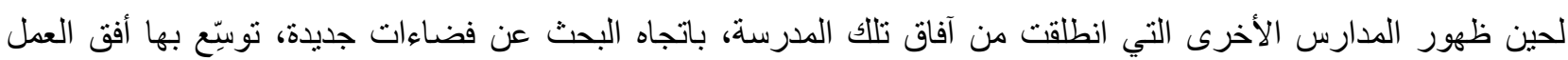
المقارن، وتثري مجالاته. لقد كانت إطلالة المدرسة الفرنسية التاريخية عندما خط بداياتها الأولى الفرنسي (آبل فيليمان) عام 1827م، بمحاضر اته المقارنة في السوربون، وإطلاقه تسمية الأدب المقارن على تلك المحاضرات (الخطيب، 1992م،70)، ثم أصبح علما مستقلا أواخر القرن التاسع عثر وبدايات القرن العشرين، إذ أضحى له منهجه الخاص الذي يفرق فيه بين ذلك العلم وبين علمي النقد الحديث وتاريخ الأدب(جمعة، 1980م، 36)، واستقام عودها بكتاب الأدب المقارن لبول فان تيغم عام 1931م؛ الذي أرسى قواعدها، و أضحت بتلك القو اعد مدرسة تقوم على أسس جادة لا لبس فيها، وأصبحت لها منهجية واضحة، فهي قائمة على التأثر بين الآداب المختلفة جغر افيا ولغويا، فعدَّ اللغة وسيلة التمييز الأساسية التي تتيح المقارنة، وهي أكثر المعايير شيوعا وقبولا، فاستبعد المقارنات التي عملت بين شاعرين، أو عملين أدبيين في اللغة نفسها، مهما اختلفت بيئة الثاعرين، أو العملين، ومهما اختلف زمانهما، كأن تكون المقارنة بين شاعر كيني وشاعر كندي، صاغا نصيهما في اللغة الإنكليزية، ومن المنطلق ذاته لم يكن مقبولا

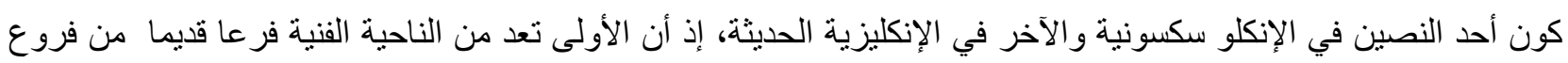
الأخرى، وبهذا فهي تنتمي إلى النظام الأدبي ذاته، وأثنار فان تيغم أيضا أن على الأدب المقارن أن يدرس تأثير كتابات أفراد الاد بعينهم، فاستبعد بذلك الأدب الثفوي، و الأدب مجهول الكاتب، و الأدب الجمعي(باسنيت، لبن 1999م، 33-35). و لا يخفى على لبيب أن مدلول الأدب المقارن مدلول تاريخي بحسب ما صدر عن المدرسة المتقدمة، إذ أنه يدرس مواطن التلاقي بين الآداب في لغاتها المختلفة، وصلاتها الكثيرة المعقدة، في حاضر ها أو في ماضيها، وما لهذه الصلات التاريخية من تأثير وتأثر، أيا كانت مظاهر ذلك التأثير و التأثر، سواء تعلقت بالأصول الفنية العامة للأجناس والمذاهب الأدبية، أو التيارات الفكرية، أو اتصلت بطبيعة الموضوعات و المواقف والأشخاص التي تعالج أو تحاكى في الأدب، أو كانت تمس مسائل الصياغة الفنية، و الأفكار الجزئية في العمل الأدبي، أو كانت خاصة بصور البلاد المختلفة كما تنعكس في آداب الأمم الأخرى، بوصفها صلصات الهات فنبة تربط ما بين الثعوب والدول، بروابط إنسانية تختلف باختلاف الصور والكتَّاب، ثم ما بمثُّ إلى ذلك بصلة، من عوامل

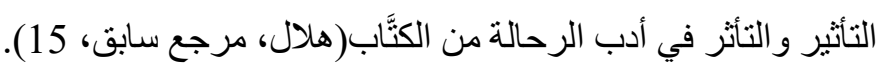


فالأدب المقارن هو((العلم الذي يبحث عن النأثر والنتأثير في الأدب على جميع المستويات، سواء أكان ذلك بين كاتب وكاتب أو

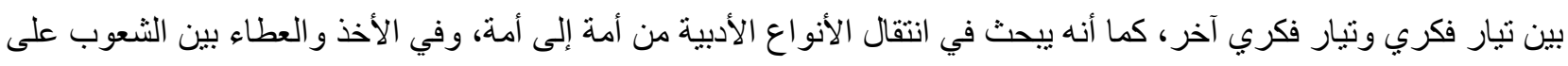

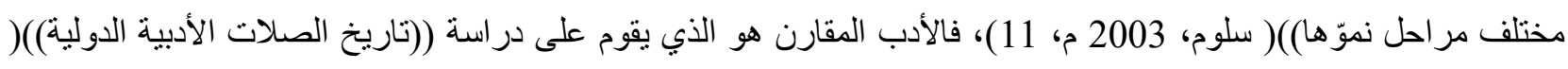

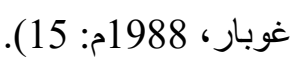

و لا يشترط بالتأثثر أن يكون نأثثرا مو افقا، فربما كان تأثثرا مخالفا (التأثير العكسي)، وهو أن يختلف كاتب في تناوله لشخصية معينة، تناولها قبله كاتب آخر، فيفرض علينا مفهو ما مغاير ا لتلك الثخصية، ومن مصاديق ذلك تناول شوقي لشخصية كليوباترة في مسرحيته المعروفة، فقد رأى فيها مثالا للمر أة الوطنية التي تقدِّم مصالح وطنها على مصلحتها الثخصية، وتضِِّي بحبها من أجل وطنها، و هذا خلاف الرؤية السابقة في الآداب الأوربية المتقدمة على زمن شوقي، فهي تر اها شخصية سلبية ماجنة غارقة في الملذات، لا تتردد في اتخاذ السبل الملتوية في الوصول إلى غاياتها، وتحقيق مآربها(هلال، مرجع سابق، 22؛ و والعشماوي،

.) 27 1994

وقد ركزت هذه المدرسة على الصلة التاريخية، أو التوثيق التاريخي، فأنشارت إلى ((أنه لا يعدُ من الأدب المقارن في شيء ما

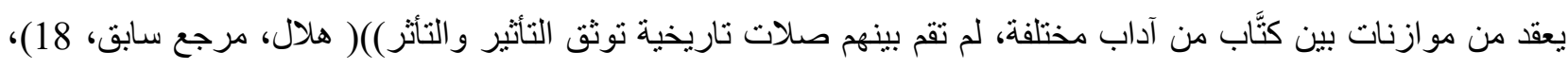
و أنشارت أيضا إلى أن الكتاب هو المستودع الحقيقي للثقافة، وهو الوسيلة التقليدية والثابتة في الحفاظ على الفكر و التراث بعامة، و الانتقال من جيل إلى جيل، وبوساطته تتبين الصلات الأدبية بين اللغات المختلفة، فالكتب هي التي تحدد لنا مدى تأثثر بلد ما أو أو الت كاتب من الكتَّاب بأي نتاج أدبي من بلد آخر، ومن الجوانب المهمة التي يقوم بها الكتاب في النقل من أدب إلى آخر قضية

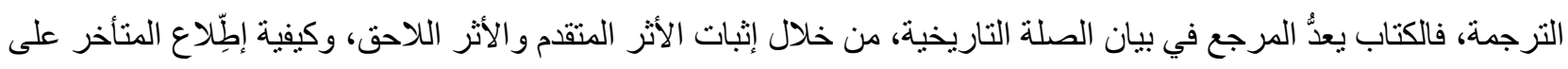
الآثار المتقدمة، وكونهاسببا لما صدر عنه من آثار أدبية(العشماوي، مرجع سابق، 29-30). إن در اسة الأدب المقارن وفق معطيات هذه المدرسة تعني الوصول إلى شرح الحقائق عن طريق تاريخي، وكيفية انتقالها من لغة إلى أخرى، وصلة نوالدها بعضها من بعض، والصفات العامة التي احتفظت بها حين انتقلت إلى أدب آخر، ثم الألوان

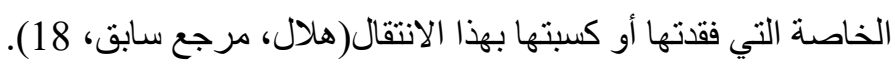
فالمدرسة الفرنسية هي المدرسة التي قامت على التأثير والتأثر، وتصر على أنه لابد من وجود وثائق، نؤكد إطلاع هذا الأديب في الأمة الفلانية على النتاجات الأدبية المؤثرة في الأمة الأخرى، فإذا لم تتوافر الوثائق انعدمت المقارنة، وهذا ما تجاوزته المدرسة الأمريكية التي انطلقت منطلقا إنسانيا ثقافيا نقديا جماليا، فلا تُعنَى بوجود الوثيقة، وتمردت على الغلى أغلب معطيات المدرسة الفرنسية، واتسعت آفاقها لتفتح الباب على مصر اعيه أمام مقارنات مستبعدة سابقا. وبعد الاستعر اض المتقدم بمكن لنا أن نوجز (معايير المدرسة الفرنسية) بالنقاط الآتية:

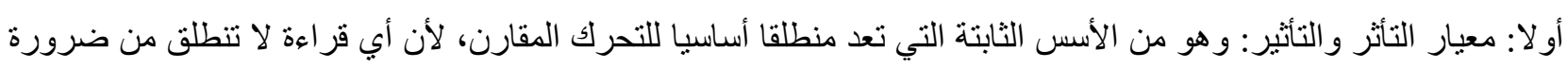
حضور هذا المعيار تخرج عن دائرة الآداب المقارنة التي تشترطو وجود قطبي التأثر والتأثير المرتبطين بالصلة. ثانيا: معيار الصلة و الوثيقة: ويقوم هذا المعيار على ضرورة حضور أدلة تاريخية، ومستندات توثيقية، بوصفها أدلة تثبت تأثر أدب معين، بأدب آخر ، أو أديب بآخر ، و هو من المبادئ المركزية أيضا في خطاب المدرسة الفرنسية المقارنة، و لا تُعد

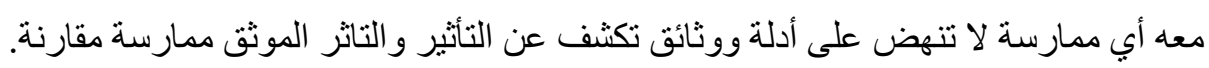


ثالثا: المعيار اللغوي الجغر افي، ونعني به ذلك المقياس الذي يقوم على قاعدة اختلاف اللغة والمنطقة الجغر افية، وهو من الأسس الرئيسة التي ينهض عليها خطاب المدرسة الفرنسية المقارن، والخطابات التي تنتمي إليه، وهو يحتِّم على الدارس به استبعاد كل ممارسة، تقوم على المقارنة بين أدبين من اللغة و الرقعة الجغر افية نفسها، من ميدان الآداب المقارنة. رابعا: معيار مادية التأثثر: يشترط في هذا المعيار أن تكون العينة الخاضعة للمقارنة كيانا ماديا ملموسا، ينسب إلى مئى أديب بعينه، وبهذا المعيار يستبعد الأدب الثفاهي، أو الآداب الجماعية الثعبية، والأدب مجهول المؤلف.

المرجعيات الثقافية

لا شك أن التمهيد بالإطلالة على مصطلح المرجعيات الثقافية ومفهومها هدفه الوقوف على دلالاته، و الموضو عات التي تندرج تحته، وإزالة اللبس عنها، نظر التعدد الرؤى وتضارب المنظرين في تحديد مسار اتها، بغية الوصول إلى رؤية محددة تسير بالبحث، وتأخذ بيده في طريقه الصحيح.

ففي السياق الموروث، لاسيما في بعده الديني والمعجمي لا نجد حضور المفردني المرجعية والمرجعيات، إذ أنهما مفردنان حديثتان، فلم يرد لهما ذكر في كتاب الله تعالى، لكن الفعل رجع ومشتقاته تكرر في القرآن الكريم مئة وأربع

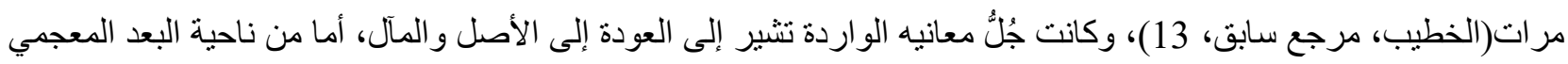
فإن المعجمات القديمة لم تتداوله، فلم ترد فيها مفردة المرجعية، و لا صيغة الجمع منها، لكنها خاضت في جذر الكلمة ومشتقاتها، فصاحب العين ذكر أن (المآب: المَرْجِع)( الفر اهيدي، د. ت، 417/8)، والمرجع مصدر ميمي واسم مكان أو زمان، بحسب سياق الجملة الوارد فيها، و العرب ((بنوا المصدر على المفعل، كما بنوا المكان عليه، ... وذلك قوللك: المرجِع، قال الله عزَّ وجلَّ: "إلى ربكم مرجعكم"، أي رجو عكم)( سيبويه، 1988م، 88/4) ، وقد ذكر الجوهري المَرْجِعُ في الآية المتقدمة أيضا، وأثنار إلى أن

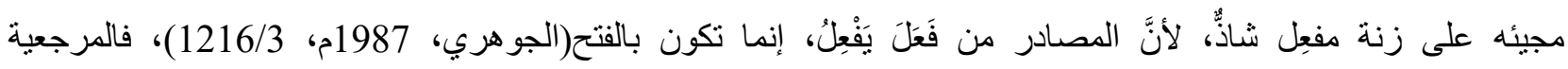

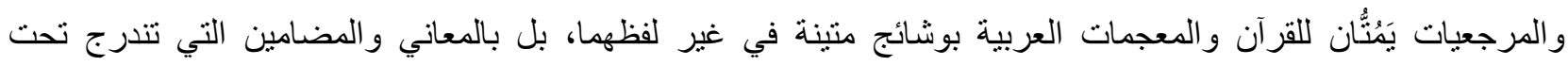

مصطلحهما.

و الثقافة هي السمات المميزة لإحدى مر احل التقدم في حضارة من الحضار ات، وتلمس فيها رقي العقل و الأخلاق و الذوق السليم في الأدب و الفنون الجميلة، وهي رياضة الملكات البشرية بحيث تصبح أتم نشاطا واستعدادا للإنجاز (وهبة و المهند، 1984م، 129)، وتعرف أيضا بأنها ((الوحدة الكاملة للسلوك المتعلم الذي ينتقل من جيل إلى الذي يليه... أو هي نمط من التقليد أو العرف، حيث تنتقل الرموز من جيل واحد إلى الجيل التالي)(( الصالح، 1999، 137). فنلحظ مما تقدم أن الدارسين انطلقوا في صياغة المصطلح من مدلوله الديني المعجمي، للوصول إلى رؤية تفضي إلى وضع الأمور في نصابها الصحيح، حول ذلك المصطلح، لكنهم قنعو ا بالخوض في ركني المصطلح (المرجع و الثقافة)، كلا على حدة، فكثرت الرؤى و الطروحات حول مفهو مه وما يندرج فيه. ويمكن لنا أن نسير مع الرؤية التي تعدُّ المرجعيات الثقافية ((مجموع الخلفيات و الأبعاد المعرفية و الفكرية والثقافية التي ينطوي تحتها الخطاب الأدبي، و عادة ما تكثف لنا هذه الخلفيات و الأبعاد، عن أيديولوجيا وثقافة أمة من الأمم في العالم، أو مجتمع من المجتمعات، ... تكثف عن عاداتهم، تقاليدهم، لغتهم، تفكير هم وغير ذلل)(( سبيعي، و بوزياني، 2019م، 257)، فحديث المرجعيات هو حديث ربط الأسباب بمسباتها وإحالتها إلى أصولها، ويمكن لـ(لمرجعيات الثقافية) أن تكون مصطلحا 
جامعا لما خاض به كتابنا القدماء في السرقات الأدبية بأنو اعها المختلفة، و الاقتباس و التضمين والتلميح، وما استشرى لاى المحدثين من مصطلحات التأثر و التأثثر، و التناص، و التلقي وغيرها، لأنها تستند جميعها إلى مرجع (أثر) وراجع إليه(متأثر)، فإن كانت المرجعيات الثقافية لنص أدبي ما محلية، كانت در استه تتضوي إلى عالم النقد الأدبي، وإن كانت خارج الحدود اللغوية

و الجغر افية لذلك النص جرت در استه على وفق معطيات الأدب المقارن.

العيّنة المقروعة في ضوع معاييز المدرسة الفرنسية:

لابد لنا ونحن نخوض في كتابات شاعر من شعر اء العصر الصفوي لنستدعي مرجعياتها الثقافية العربية، أن نبسط القول في المناخ الحضاري لذلك العصر بشكل عام، والبيئة الأدبية التي واكبت حياة الثاعر، وسارت بشعره المسار الذي رسم ملامحه، ووجَّه كتاباته، بشكل خاص، و لابد لنا أيضا أن نذكر الكيفية الني تأثر بها، ونطر ح رؤية معضدة بالحجج على نأثره بالموروث العربي الإسلامي، مبينين الصلة التاريخية التي ربطت نتاجاته بذلك الموروث. لقد عاش الثاعر وحشي البافقي في العصر الصفوي الذي قام بأنفاس العائلة الصفوية، ذلك العصر الذي كانت الناحية المذهبية عنو انه العريض، و هو العنوان الذي انبثقت منه السياسة الداخلية والخارجية لذلك العصر، و الصفويون بنسبون إلى جدهم صفي الدين الأردبيلي(650- 735ه) الذي كان تركيا، واللغة التركية لغته المتداولة في مجالسه، وقد انتقلت إليه مشيخة الطريقة الصوفية بعد وفاة رائدها الثيخ الزنجاني الذي كان الأردبيلي من أقرب مقربيه وزوج ابنته، وتوارثها بعده أبناؤه، ويعد الثاه إسماعيل الصفوي، الابن الثالث لحيدر بن جنيد حفيد صفي الدين، المؤسس لدولة الصفويين، وقد اتخذ اللغة الفارسية لغة رسمية، و المذهب الجعفري مذهبا وحيدا في دولته(أبو خليل، 16،2005، 18)، وقد خلفه ابنه الثناه طهماسب (930-10984 15241576م) الذي عاش الثاعر في زمنه، وقد أنشارت بعض المصادر التاريخية إلى أنه أول ملك في الأسرة الصفوية يدَّعي النسب

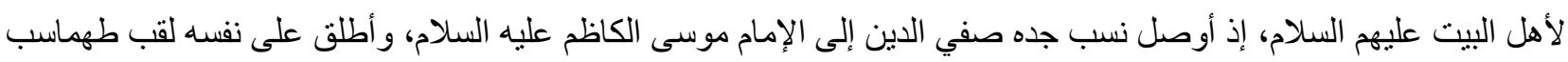
الصفوي الحسيني الموسوي، حامي الدين، ثم تبعه الملوك الذين جاءو ا بعده(فلسفي، 1989، المقدمة و ). إن الدارس لتاريخ هذه الدولة يلحظ أن إسماعيل الصفوي إن كان نجح في إرساء قو اعد الحكم، فإن الثاه طهماسب كان له دور مهم في تدعيم هذه الدولة، وإن أسلوبه قد اختلف عن أسلوب أبيه، فرغم أنه كان ملكا حازما، تعاظمت في عهده الدولة الصفوية، وازدادت قوة ومنعة، وانحسر فيها الفساد والإفساد، إلا أنه كان أوسع حيلة و أكثر لينا من أبيه، ونتشهد المذكَّرات التي كتبها بذللك، على أن أهمية حكمه لا نكمن في تطهير البلاد من الفساد، وفي تنبيت الجانب العقائدي في أنحاء إيران، بل إن هذا الملك أفلح في الحصول على اعتراف رسمي من أعدائه العثمانيين، بدولته وعقيدتها، فأبرم معاهدة مع السلطان سليمان القانوني(عبد المؤمن، 1978م، 33-34).

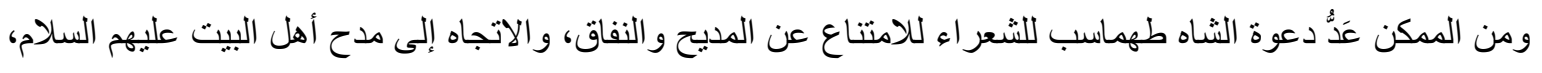
وتقدير مآثرهم، وتسجيل أعمالهم، ورثاء من استشهد على الدعوة لأهل البيث الكرام عليهم السلام منهج(عبد المؤمن، مرجع سابق، 35)، توجيها لبوصلة الأدب و الأدباء للسير به وبهم نحو التحليق في فضاءات الأئمة الطاهرين عليهم السلام، و إذنا عاما للشعر اء بالدخول إلى عالم الأمراء، ونوالهم من خلال هذا الغرض، ومن ناحية أخرى يدل ذللك على توجه الدولة الصفوية في عهد ذللك الملك باتخاذ أسلوب الحجة والدليل، في الدعوة إلى مذهب أهل البيت عليهم السلام، وهو الأمر الذي صبغ النتاجات الشعرية بعامة، ونتاجات الثاعر وحشي البافقي بخاصة بالصبغة المذهبية آنذاك، وحتَّم عليهم تحديد مسار خطابهم الأدبي بحيث 
ولما كان البحث قد ألزم نفسه بمعايير المدرسة الفرنسية، فإن ما تقدم يمثل حضور ا واضحا لمعيار الصلة التاريخية التي

تتعلق بالدليل الناهض بانسياب المؤثرات العربية الإسلامية إلى الثاعر، و إمكانية تأثره بها، و هذا يستدعينا أو لا للبحث عن الأدلة التي نتير إلى اضطلاع الثاعر باللغة العربية، فأغلب الظن أن الإلمام بمعارف مختلفةٍ انعكست صور منها في شعره، كان نتيجة

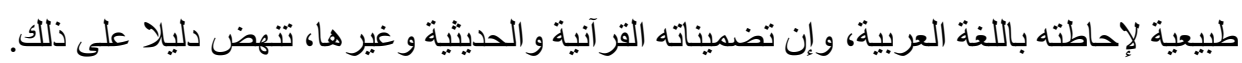
فالثاعر يقر بعمث صلته بالعربية ولغتها، فيقول ما ترجمته: الناي والبيغاء واحد، فأي عجب، هذا كلام عربي وليس عجميا.

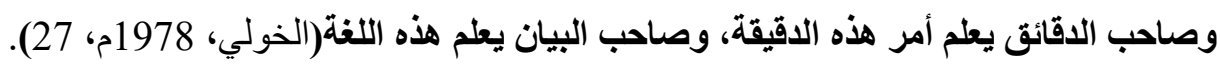
ويستدعينا ثانيا إلى البحث عن هجرة الثاعر، ووصوله إلى العر اق، وبقائه هناك مدة تمكنه من الاطلاع على الآثار العربية الإسلامية التي كانت تغص بها المكتبات هناك، سو اء في المدن المقدة التي لابد لعقبدة الثاعر من حمله إليها، أو المدن الأخرى

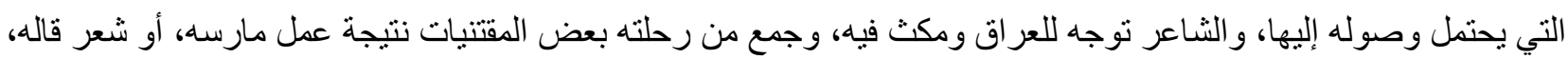
في مدح هذا أو ذاك، يقول الثاعر ما ترجمته: ألا تعلم أنه في سبيل تدبير معاشه باع وحشي المشرد كلما امتلكه

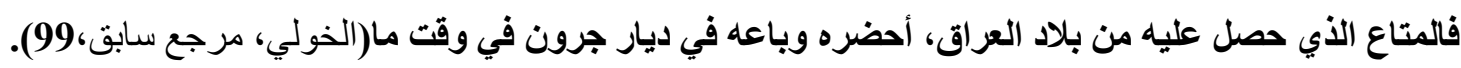

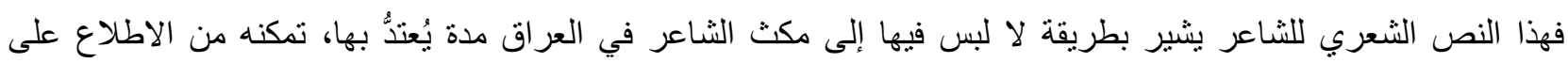
الموروث العربي الإسلامي من مصادره الرئيسة. الأمر الآخر الذي يستحق الإشارة إليه يتمثل في الجانب العقائدي الذي قامت عليه الدولة الصفوية، ويتجسد بالفكر الإسلامي بعامة، وفكر مدرسة أهل البيت الكرام بخاصة، فالقرآن الكريم، والأحاديث النبوية الثريفة، وأحاديث أهل البيت الكرام ورواياتهم، وسيرة أئمة تللك المدرسة الكبيرة، وبخاصة سيرة الإمام الحسين عليه السلام، وما جرى عليه، و أهل بيته من مصائب، كل ذللك بات منيسر اللخواص و العوام، فضلا عن كون الدولة الصفوية منذ بدايتها أصبحت مكان استقطاب لعلماء مدرسة أهل البيت من كل مكان، ومن ذلك ما استشرى من حديث عن الهجرة العاملية، وهي هجرة علماء جبل عامل الثيعة، وعلى وجه الخصوص في عصر الثاه طهماسب الذي يعرف بالمصادر الفارسية(شاه دين بناه)، أي حامي الدين، وقد أُثير إلى أن ذلك اللقب اكتسبه بجدارة، ففضلا عن كونه عظيم التديُّ، فإن عهده كان العهد الذهبي للمهاجرين العامليين، الذين انتشروا في بلاده من أدناها إلى أقصاها(المهاجر، 1989، 19: 11). ولا يمكن إغفال دور الخطاب المنبري و الثعائر الحسينية في تأسيس البنية العميقة لثقافة الثاعر، وما أثيع من تداخل في الثقافات في عهد الثاه طهماسب ولاسيما الثقافتين العربية والفارسية، فر( بعد أن أعلنت الدولة الصفوية عن مذهب الدولة الرسمي، كان عليها الالتزام بالثعائر الحسينية لما لها من محورية في التشيع، خصوصا في بداية تأسيس الدولة الصفوية، وتشدّدها في أمر التشيّع؛ لذا أصبحت الثعائر الحسينية في هذا العهد بمثابة الثعار للشيعة)) (الساعدي، 2016م، 95)، كل ذلك يمثل وثائق ر اسخة لتتبع فكر البافقي وتنشبُع شخصيتة الثقافية بتلك الفضاءات الروحانية المؤثرة. لقد عاش الثاعر وحشي البافقي في هذه الأجواء التي استنشق نتاجاته منها، فأضحت صلته بالموروث العربي الإسلامي أمرا طبيعيا، فقر أ القرآن وكتب الأدعية و الزيارات بالعربية، كأي مسلم موال لأهل البيت عليهم السلام، وكانت تلمذته علي يد الثيخ الثناعر شرف الدين علي البافقي الذي ((كان وافر العلم والدين، ويمتاز عن بقية أكابر الديار بمزيد من الفضل والتعفف، وكان 
مشغو لا على الدوام بالتدريس و الفتوى))( البافقي، مرجع سابق، 97)، مما يؤصل التأثر بالموروث الديني العربي الإسلامي، فلا

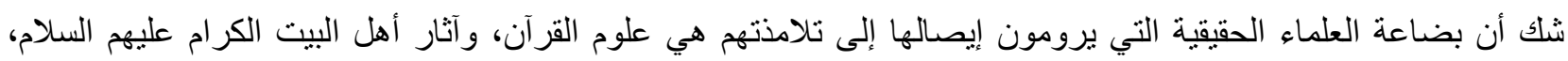
وبذلك تكون حلقة تأثر الثاعر قد اكتملت، وإن إحالة كثثر من نتاجاته إلى مرجعياتها العربية الإسلامية بات أمر ا مقبو لا، و أصبح انضو اء الدر اسة إلى ميدان الأدب المقارن بحسب معطيات المدرسة الفرنسية المقارنة مدعما بالوثائق التي تدخل في شر ائط تلك الكي مئك

المدرسة المقارنة أمر ا محسوما.

المبحث الثاني: البعد الإجرائي

إن الخوض في المرجعيات المختلفة لما سمي بالنصوص الإبداعية، و التمعن فيها تجعلنا نبحث عن مفردة منو اضعة تخفق من

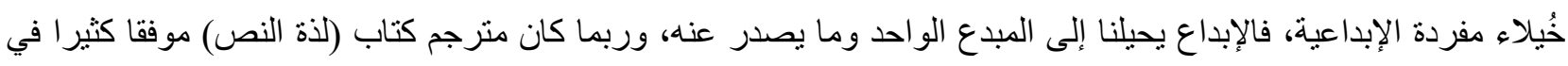

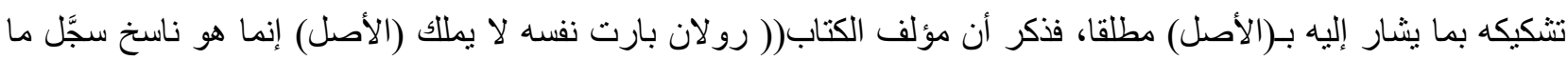

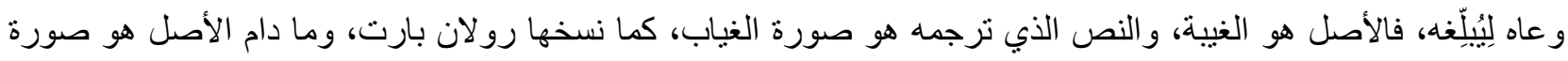

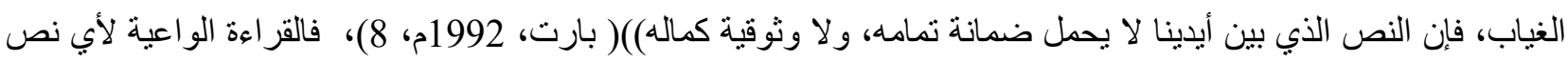
من تلك النصوص تحيلنا إلى مغذياته، والطبيعة التي أفضت إلى تشكُله، وبيان علائقه الوثيقة بمرجعياته المختلفة. و الثشاعر وحشي البافقي كغيره من الشعر اء مُدَّتْ بين نصوصه الشعرية الكثيرة وبين مرجعياتها المغذية جسور واصلة،

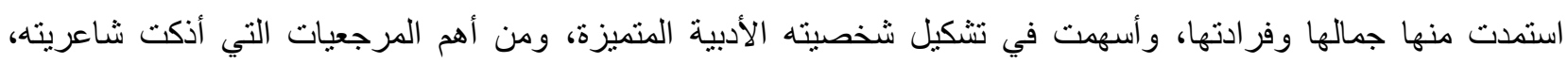
و أكسبتها رونقها، هي المرجعية القرآنية، تلك المرجعية التي تستحق وحدها أن يشار إليها بالإبداعية، لأن مبدعها أصل تؤول إليه الموجودات كلها، فكانت أهم المرجعيات التي اغترف الثاعر منها نصوصه الثعرية، فتجلت في كثير منها بصورة مباشرة أو

غير مباشرة.

إن الحديث عن مرجعيات الثاعر وحشي البافقي يجعلنا نستدعي نتاجاته بصورة إجمالية لنقوم باستنطاقها فيما اكتنزت به من مؤثرات كثيرة، فقد تمحورت أعماله الثعرية المثرجمة حول ثلاث منظومات هي (خلد برين)، و(ناظر ومنظور)، و(فر هاد وشيرين) (الخولي، مرجع سابق،325)، وقد شكلت المعاني الدينية مدخلا مهما وكبير التلك المنظومات، مهما كان

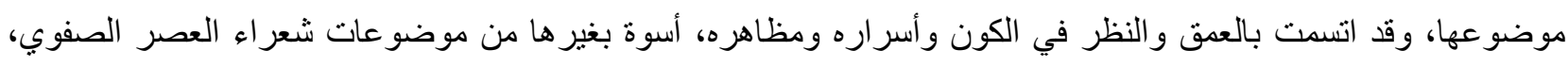
و هو ما يتلائم مع الانقلاب الديني و المذهبي الكبير الذي اجتاح البيئة الإير انبة، وكانت تتدرج تدرجا طبيعيا، في إثبات وجود الله، ووحدانيته، وما يترتب على ذللك من حمد وتسبيح وتكبير ودعاء وتوسل بالرسول الكريم، وأهل بيته الكر ام، و التعرض للمصائب التي ألمت بهم(عبد المؤمن، مرجع سابق،162-163).

المرجعيات القرآنية المباشرة:

من الممكن أن نقول باطمئنان أن المرجعيات القرآنية المباثرة تعني تداخل نص أديب ما مع النص القر آني تداخلا، بحيث يصدر معنى نصه وشكله عن معنى النص القر آني وشكله، فيستدعي الثاعر آية قرآنية، أو جزءا منها، وقد كان لهذا النوع من التأثر نصيب كبير في نصوص الثاعر وحشي البافقي، ولا بد لنا في هذا الحال أن نلفت النظر إلى أنه في تأثره المبانشر في الآيات القر آنية الكثيرة التي وردت في شعره لم يترجم هذه الآيات إلى الفارسية، ولم يتصرف بها، بل اعتمدها بنصها القرآني 
العربي المبين كما هو، وهذا التداخل الرائع في داخل النص الثعري أكسبه جمالا مضاعفا، وكان التوافق الفريد بين نصوصه، وتضميناته القر آنية يحيلنا بلا شك إلى تمكن الثاعر من لغة القرآن وتفسيره، وما حمله الموروث الإسلامي الثيعي الذي يعتمل في داخله بجزئياته الدقيقة، وتسخيره لتأدية المعنى المقصود في نصوصه الشعرية، ونظر العمق تأثر الثاعر بالمرجعية القرآنية المباثرة، مما أدى إلى شيو عها، سيعمد الباحث إلى جدولة أهم نماذج هذه المرجعية، ومن ثم الوقوف على بعضها مما يمكن من خلاله استجماع النتائج الذهنية المُفضية إلى توضيح صورة تلك الاشتغالات، لتكون عيّنة إجرائية:

\begin{tabular}{|c|c|c|c|c|}
\hline النص القرآني المؤثر & السورة والآية & نص الثاعر المتأثر & في الديوان & 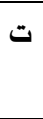 \\
\hline 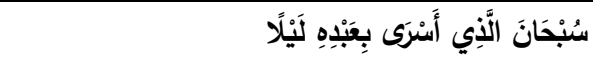 & إسراء، آية 1 & يا محمد الساري (أسرى بعبده) & 102 & 1 \\
\hline وَأُخْرَى تُحِبُونَنَهَا نَصْرُ مِنَ المَّهِ & الصف، آية 13 & لواء النصر (نصر من الله) & 102 & 2 \\
\hline 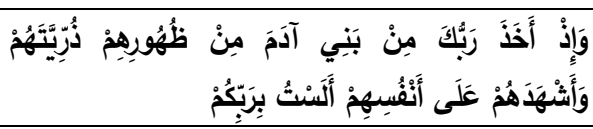 & آلأيةراف، & ندن في هذه الحانه سكارى، ما دام فيها & 102 & 3 \\
\hline وَلَمْ يَكُنْ لَهُ كُفُقًُا أَحَدُ & الإخلاص،آية4 & 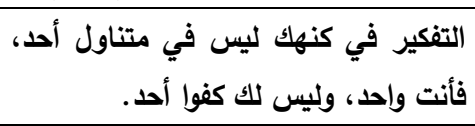 & 103 & 4 \\
\hline 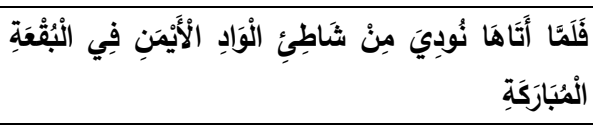 & آية القصص، & كلا تبحث عإن كله مضيء الوادي الأيمن من أجل نار عين موسى. & 104 & 5 \\
\hline 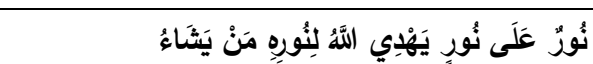 & النور، آية 35 & جبينه (نور على نور) & 110 & 6 \\
\hline
\end{tabular}

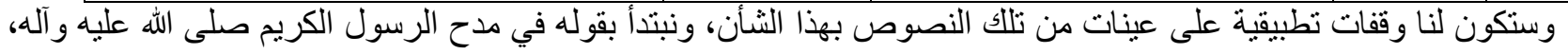

ما ترجمته:

يا محمد الساري (أسرى بعبده)، أعط الزمان ترتيب عقد النهار والليل (الخولي، مرجع سابق،102). إن هذا البيت الذي يمدح به الثاعر نبي الرحمة محمدا صلى الله عليه وآله، ضمَّن الثاعر فيه نصا قر آنيا من الآية الأولى من

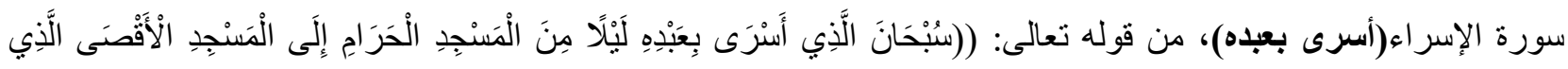

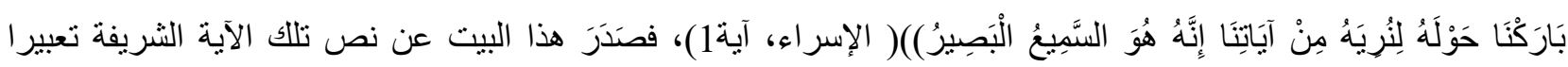

ومحتوىً.

ونلحظ أيضا في قر اءتتا للنص الشعري المتقدم أن حيويته تكمن في الرئة القرآنية التي مدَّته بأنفاسها، والحضور النبوي الذي انفتحت ذات الثاعر على شخصه الكريم، فانصهرا في بوتقة الثاعر، لينتجا نصا إنسانيا خالدا، امتزجت فيه عربية القرآن الصادرة عن الذات الإلهية المقدسة، بالتو هج الرسالي العظيم ببعده الإنساني، وبفارسبة الثاعر المتفنن في توجيه بوصلة إيقاع

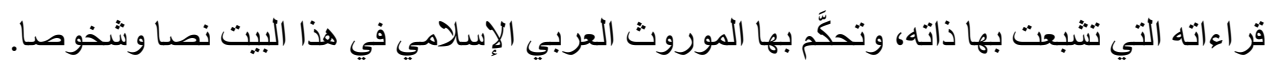
و لابد لنا ونحن في أجواء هذه الآية التي وظفها الثاعر في نصده المتقدم من الإشارة إلى أنه كان مسكونا بقصة الإسراء و المعر اج، فقد وقفنا على إفراده المقالة الرابعة في منظومة (ناظر ومنظور)، و إعطائها مساحة كبيرة في منظومته (فرهاد

وشيرين)، وهي تدخل في باب التأثر غير المباشر(الخولي، مرجع سابق، 351-352، 382-381). ومن النماذج التي تقع ضمن المرجعيات القر آنية النص الشعري الذي يمدح فيه الثاعر الإمام علي عليه السلام، ما ترجمته: جعل الله في رفقته من أجل الفتح لواء النصر (نصر من الله) (الخولي، مرجع سابق، 102). 


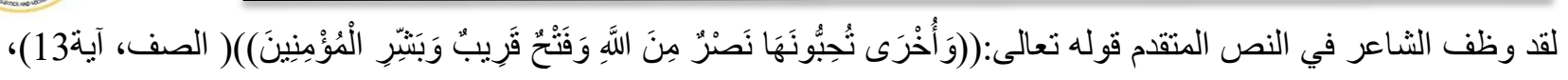
و هو نص لم يستدعِه الثاعر من هذه الآية جزافا، فالموروث الإسلامي منقل بروايات البطولة التي رويت عن مآثر ذلك البطل

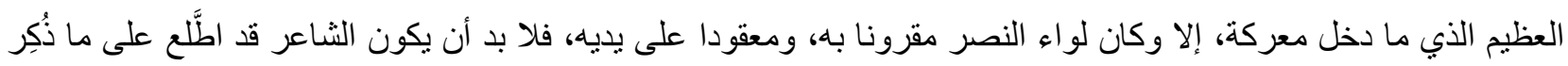
أيضا في المصادر التاريخية عن نقش خاتم الإمام علي في الحرب، فقد ورد في نقوش خو اتيم أمير المؤمنين - عليه السلام ((على بلى الفص العقيق و هو خاتم الصلاة: لا إله إلا الله، عدة للقائه، وعلى الفص الفيروزج و هو للحرب نصر من الله وفتح قريب، وعلى الفص الياقوت وهو لقضائه الله الملك و على عبده، "[وفي نسخة وهو للقضاء: يا الله الملك]، و على الفص الحديد الصيني وهو لختمه " لا إله الا الله محمد رسول الله"))( ابن البطريق، 1987م، 31) ، فهنا ينكثف لنا السر الذي جعل الثـاعر ينتقي هذا النص من الآية المذكورة، دون سواه من الآيات المشهورة التي ذكرَ كثيرٌ من المفسرين أنها نزلت في الإمام علي عليه السلام، فاستند

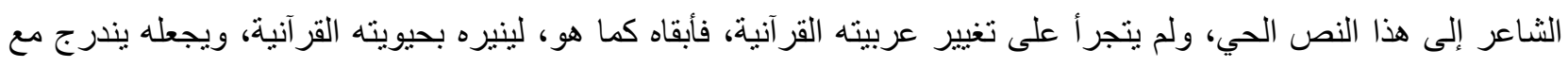

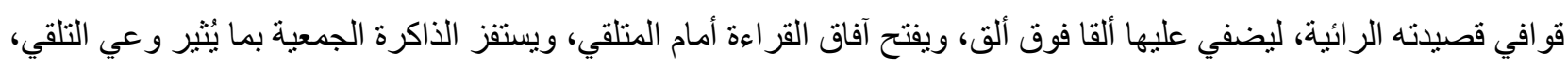
ويدعوه إلى البحث و التنقيب عن سر استدعاء هذه الجزئية من الآية القرآنية، في نص يرسم لنا مشهد البطولة، ويؤسس لحضور مرجعية ثقافية مزدوجة قر آنية تاريخية، في بيت ملمَّع بالتشكيل الفارسي العربي. ومما ينتمي للمرجعيات القر آنية المباشرة، قوله في مدح الإمام علي عليه السلام أيضا:

من جبينه نور وادي الطور، جبينه (نور على نور) (الخولي، مرجع سابق، (110).

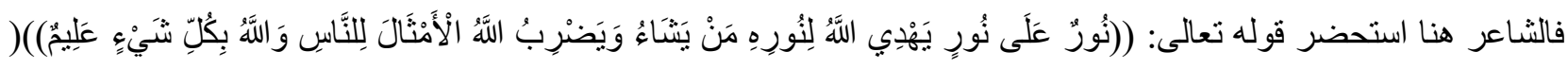
النور، آية 35)، ويبدو أن اصطفاءه لهذه الآية تحمل لنا إنشارة عن عمق استيعابه للموروث الإسلامي الثيعي، إذ إنه يحيلنا إلى ما لـاءئ ورد في (الكافي) من روايات تفسيرية لهذه الآية، تتجلى فيما روي عن أبي عبد الله الصادق عليه السلام في تفسيره لقول الله تعالى:

((نور على نور "إمام منها بعد إمام" يهدي الله لنوره من يشاء" يهدي الله للأئمة من يشاء")) (الكليني، 1985م، 195/1) ، فيكون قد وظَّف الآية المناسبة لمدح الإمام علي عليه السلام، بعد استقصاء الخزين المعرفي الكامن في ذاته، واستلاله تلك الآية المناسبة لصورة المدح الواردة، محملة بالرؤية التفسيرية التي تربطها بأمير المؤمنين والأئمة الطاهرين من أبنائه عليهم السلام (نور على نور). وقبل أن نغادر هذا النموذج إلى نماذج أخرى، لا بد لنا أن نلتفت إلى ما فيه من إضاءات قرآنية أخرى، فنلمس في هذا البيت الثعري تكثيفا مذهلا في نوظيف الاستدعاء القرآني، وهذا ينم عن موسوعية مذهلة في استيعاب التراث الإسلامي الثيعي، و التصرف به بمهنية عالية، فهو عندما يقول (من جبينه نور و ادي الطور)، يكون قد صاغ بيتا شعريا قر آنيا خالصا، لم ييق فيه متنفسا لغير القرآن ودلالاته المتعددة، فعن الإمام الباقر عليه السلام في حديث أنه كان في وصية أمير المؤمنين عليه السلام، ((أن

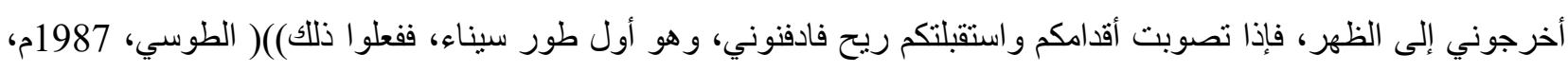
32/6)، فدلالة وادي الطور بحسب الروايات الراكزة في منظومة الثاعر الفكرية، ومنها الرواية المتقدمة، تنقله إلى ضريح الإمام علي عليه السلام الذي أنار ذلك الوادي المقدس، فرواية الإمام الباقر عليه السلام كانت حاضرة بين يدي الثاعر، وأدَّت غرضها في المز اوجة القر آنية التاريخية أيضـا. 
و هي المرجعيات التي ينطلق نص الثاعر فيها من فكرة أو قصة أو رمز قرآني يتناص معها لإعادة إنتاجها بطريقة جديدة،

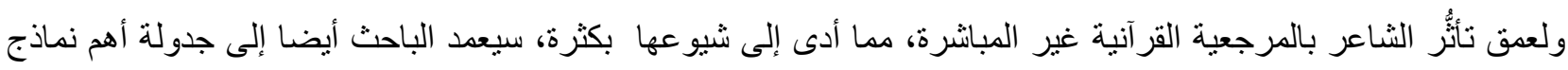

هذه المرجعية، ومن ثنَّ الوقوف على بعضها، لتكون عينة إجر ائية:

\begin{tabular}{|c|c|c|c|c|}
\hline النص القرآني المؤثر & السورة والآية & ل اعل اعر المتأثر & في الديوان & ت \\
\hline 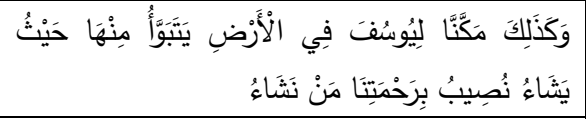 & آية & لقد حصلنا على يوسف ثانية فليس من قحط يا & 98 & 1 \\
\hline 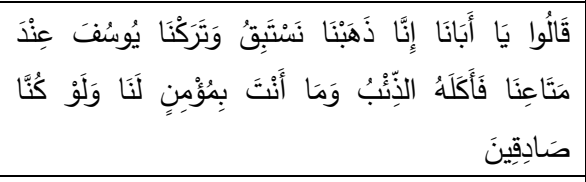 & 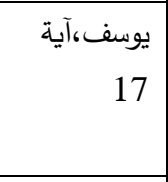 & لقظد أصابوا روحي بوشم يعقوبي، وأسلموكِ-أي & 103 & 2 \\
\hline 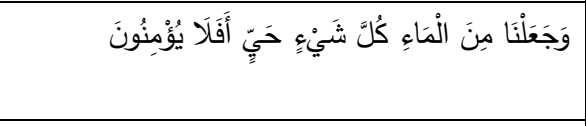 & الأنبياء، آية & فإنه يرتعد من العرى بفعل رياح الثتاء الجاري رغم أنه مانح الحياة، & 11 & 3 \\
\hline إِرََّ ذَابِ الْعِمَادِ & الفجر ،آية7 & دار أمان، أو روضة أرم، أو روضة دار القرار & 217 & 4 \\
\hline 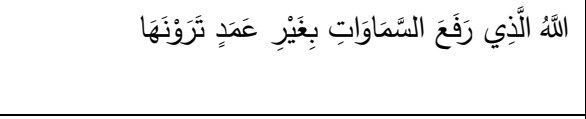 & الرعد، آية2 & 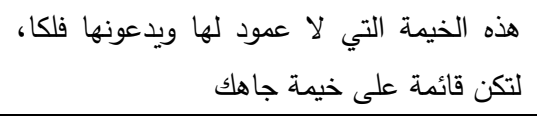 & 241 & 5 \\
\hline 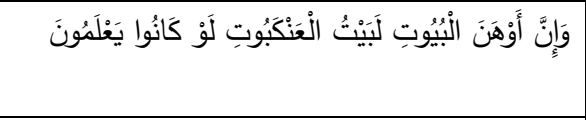 & 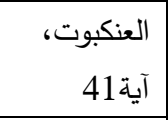 & لا يمكن أن تكون خيوط العناكب عقالا للناقة & 245 & 6 \\
\hline 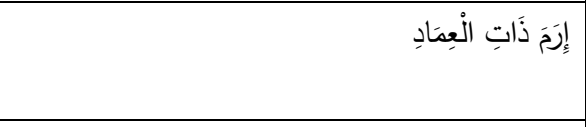 & 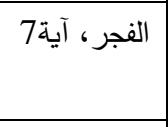 & وبستان أرم وهذه الرياض حول الحرم قصر حور & 249 & 7 \\
\hline 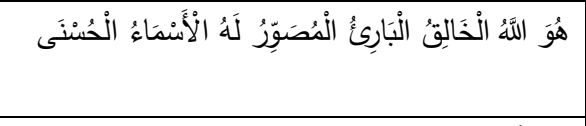 & الحشر، آية & 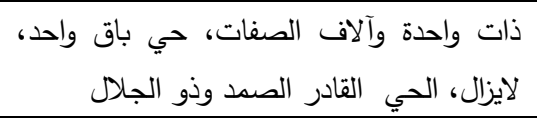 & 329 & 8 \\
\hline مَذْكُرًاً & 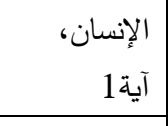 & 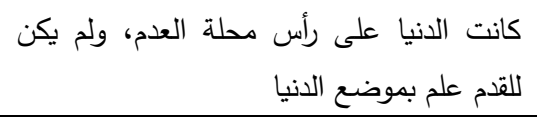 & 329 & 9 \\
\hline 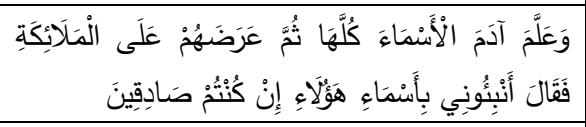 & $\begin{array}{r}\text { البقرة، } \quad 31 \\
\end{array}$ & على الملائكة عرضته على الملائكة، فرضت السجود له & 347 & 10 \\
\hline 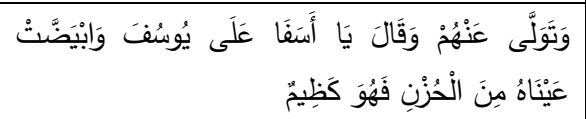 & يوسف، & 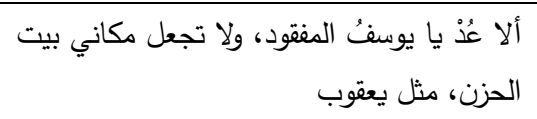 & 367 & 11 \\
\hline
\end{tabular}

وأول نص سنتعامل معه من نصوص الثاعر في التأثر غير المباشر هو قوله، ما ترجمته:

لقد حصلنا على يوسف ثانية فليس من قحط يا وحثي، ألسنا في مصر. يعني مدينة كاثـان(الخولي، مرجع سابق، 98). استحضر الثاعر في هذا النص الشعري سورة يوسف، والخير العظيم الذي أصاب مصر ببركة ذلك النبي الكريم، وبخاصة قوله

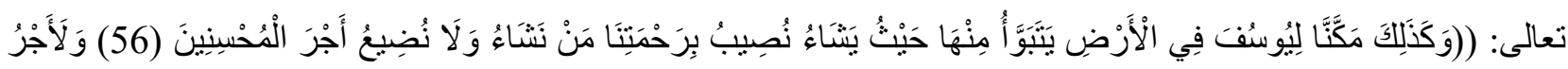

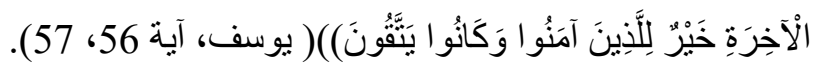


و هذا النص قاله الثاعر عندما تخلص من مسقط رأسه في (بافق) ، و اتجه أول ما اتجه إلى يزد، لكن يبدو أنه لم يجد فيها فرصة عمل، فارتحل إلى كاثان، حيث قضى فيها فترة وجيزة بعلِّّم نشأها في إحدى المدارس، وقد تمكن في كاشان من الاتصـال بمحد سلطان حاكمها، وأحد الذين كانوا يرعون الأدب، ويولون الثعر اء أهمية كبيرة، مما ساعد على رواج سوق الثعر في المدينة، ووحشي رسم لنا صورة لذلك في النص المتقدم(الخولي، مرجع سابق،98)، مستحضر ا صورة النعيم الذي ظفر به يوسف عليه

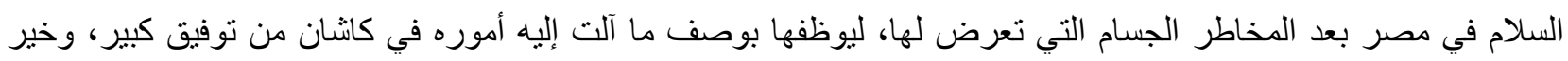

عميم.

و الظاهر أن الشـاعر كان شغفا بهذه السورة الثريفة فقد صدرت كثير من نصوصه الثعرية عنها، ومن ذلك قوله، ما ترجمته: لقد أصابوا روحي بوشم يعقوبي، وأسلمولِِ-أي منظور- إلى الأنب كيوسف(الخولي، مرجع سابق،103). فنلحظ في النص المختار أعلاه أن الثاعر لا زال منمسكا باستدعاء صور مختلفة من سورة يوسف، في موضو عاته المتنوعة،

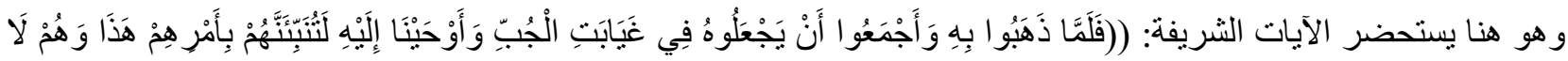

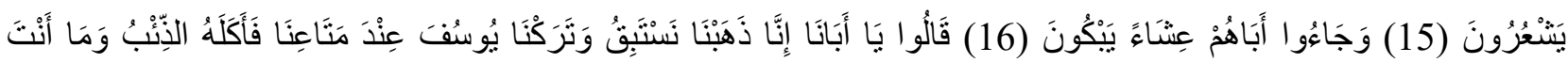

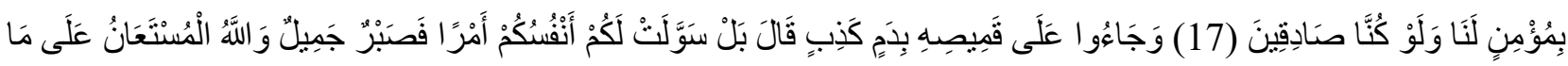

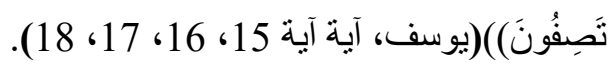
فهو يثير إلى مفهوم قصة يوسف وأخوته ووالدهم يعقوب، وقد قال ذللك النص في منظومته (ناظر ومنظور ) على لسان ملك الصين، عندما أخبروه أن منظورا ابنته قد تركت قافلة الصيد في الصحر اء، وهربت عند السحر من أجل البحث عن ناظر حبيبها(الخولي، مرجع سابق،103)، فعلى الرغم من كون موضوعه يتعلق بقصة حب عذري أفرغ فيها الثاعر ما يكابده من حب و عزلة، إلا أنه بقي مأسورا بالتوظيف القر آني المهيب المكتنز في هذه السورة، لما له من دور في تكثيف النص واستجلاء معانيه وشد المتلقي إليه. ومن النماذج اليوسفية الأخرى التي استلهمها الثاعر من نللك السورة العظيمة، قوله على لسان ملك الصين في المنظومة ذاتها مو اسيا نفساه، ما ترجمته:

ألا عُدْ يا يوسفُ المفقود، ولا تجعل مكاني بيث الحزن، مثل يعقوب(الخولي، مرجع سابق، 367).

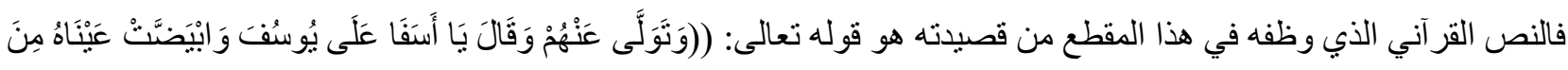

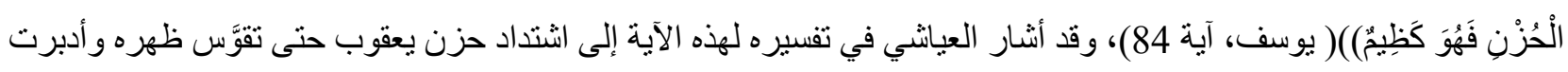
الدنيا عنه، فالتأسف هو أثند الحزن، وإن حزنه يعدل حزن سبعين نكلى بحسب حديث الإمام الصادق عليه السلام الذي نقله صاحب التفسير(العياني، د. ت، 2/ 190)، فموضوع الآية فضلا عن كونها نص قر آني كريم، فهو موضوع إنساني يتحدث عن عاطفة محمومة لأب مفجوع بفقدان ولده، فاستحضره الثاعر في منظومته ناظر ومنظور ، لينطق به على لسان الملك الذي فقد ابنته (منظور)، ويناديها بيوسف المفقود، فالثاعر هنا وإن كان قد تجاوز التناص الحرفي في تضميناته، فقد عمد على اسلوب الاستبدال، ليستدعي من خلال ذلك الاسم أملَ اللقاء، ولو بعد حين، ويستدعي صورة الحزن القرآني المعتمل في صدر يعقوب،

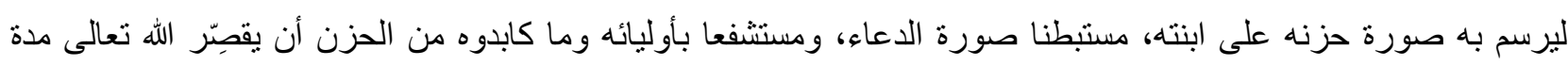
الفراق، ويجمع شمله بابنته المفقودة. وفي نموذج آخر للشاعر مما ابتدأ به منظومته ناظر ومنظور ، تحدث فيها عن خلق آدم، يقول ما ترجمته: 
ومن ذلك التراب جعلت كيانا، وهو لكنز عشقلك طلسم

ولما عرضته على الملائكة، فرضت السجود له على الملائكة

فلم يو افق أحدهم على السجود له، فحمل طوق اللعن في رقبته(الخولي، مرجع سابق، ويتضح لنا من خلال الوقوف على مفردات هذا النص الشعري المترجم، ومعانيه المكثفة أن الثاعر قد وضع كلَّما قيلَ من آيات كريمة في خلق آدم، وعرضه على الملائكة، وأمره تعالى الملائكة بالسجود له، و عصيان إبليس لأمر الله تعالى، وقصة لعنه من لان الذات الإلهية المقدسة، نصب عينيه، و هو ما تناولته الآيات من (30- 34) من سورة البقرة، والآية (59) من سورة آل عمران، والآيات من (11-18) من سورة الأعراف، والآيات من(61-63) من سورة الإسراء، والآية(50) من سورة الكهف، و الآية (116) من سورة طه، والآيات من (71-78) من سورة ص، ويمن لنا عد الآيات الأخيرة المشار إليها من سورة ص قد الد أجملت ما ضمَّنه الثاعر في أبياته من معان قر آنية بصورة غير مباشرة إلى حد كبير. ففي البيت الأول ينفتح النص المتقدم ليستقي من معين أكثر من آية في أكثر من سورة، فمعانيه مقتبسة من قوله تعالى: ((إذذّ قَالَ

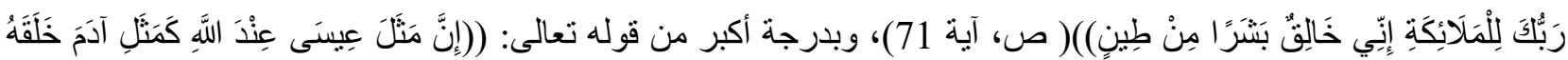

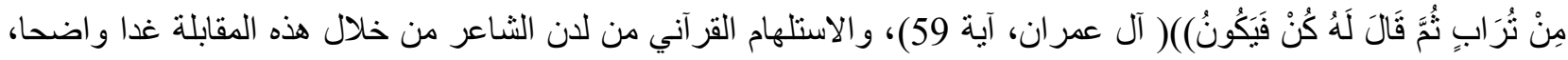

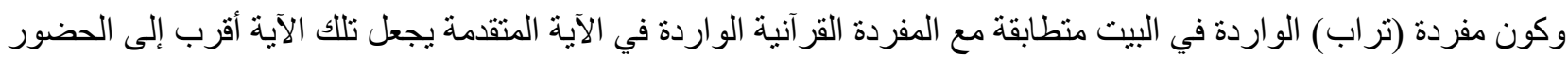
في خلد الثاعر لحظة كتابته لذلك البيت. لقد استحضر الثناعر _كما تقدم- القصة القر آنية لخلق آدم، وسار معها في أبياته بالتسلسل القر آني ذاته، فهو ينتقل في بيته الثاني

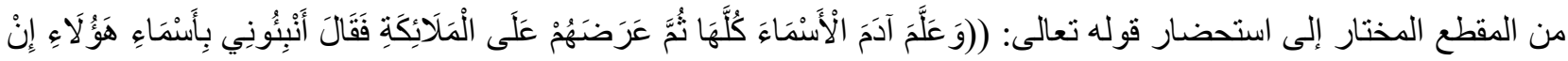
كُنْنُمْ صنادِقِينَ)( (البقرة، آية 31)، فقضية فضل آدم عليه السلام، وتبيينه للملائكة ما لم يكن يحيطوا علما به، بأن علم آدم الأسماء كلها، ثم عرضهم على الملائكة؛ ليظهر بذلك كمال فضله، وقصور هم عنه في العلم، قد استلهمه الثاعر في ذلك البيت، فضلا عن حضور الموروث الإسلامي الثيعي، الذي يشكل هاجسا ومحركا لثاعرية البافقي المستوعبة لجزئيات ذلك الموروث، ويتمثل ذللك بالتفسير الذي يذهب إلى أن الأسماء التي و عاها آدم عليه السلام في قوله تعالى(و علَّم آدم الأسماء كلها) هي أسماء أنبياء الله ، و أسماء محمد صلى الله عليه و آله، و علي وفاطمة والحسن و الحسين عليهم السلام، والطيبين من آلهما، وأسماء خيار شيعتهم، و عتاة أعدائهم (ثم عرضهم - عرض محمدا و عليا والأئمة ـ على الملائكة)، أي عرض أشباحهم وهم أنوار في الأظلة(الإمام العسكري عليه، 1989م، 217)، وهذه القراءة للنص القرآني لا تمنع القر اءات الأخرى له، ولكننا ارتأينا الوصول إلى الفهم الذي أي

يسوقه الثاعر لمتلقية بحسب الفضاء العقائدي لزمن الثاعر وبيئته. و عند انتقالنا إلى المقطع الثاني من الييت الثاني (فرضت السجود على الملائكة)، والمقطع الأول من البيت الثالث (فلم يوافق أحدهم على السجود له)، تداعت إلى أذهاننا آيات كريمة عدة، من المؤكد أنها كانت مرجعية للثاعر في بسطه لتللك المعاني، أولها

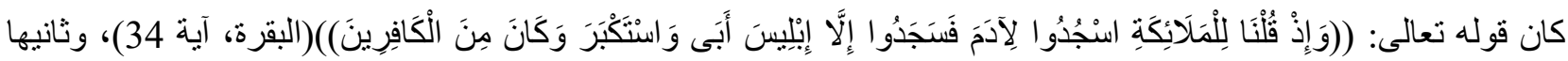

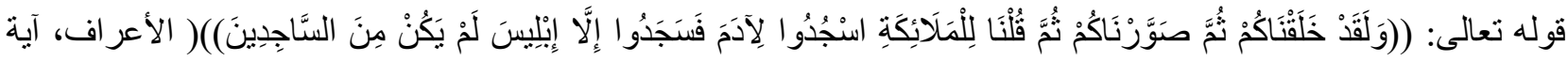

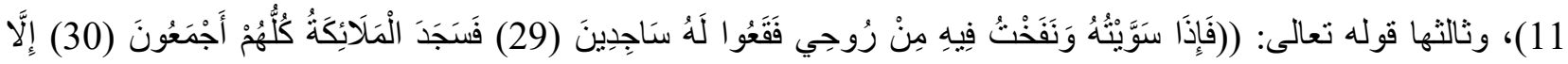

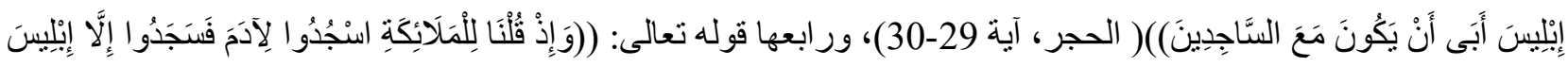

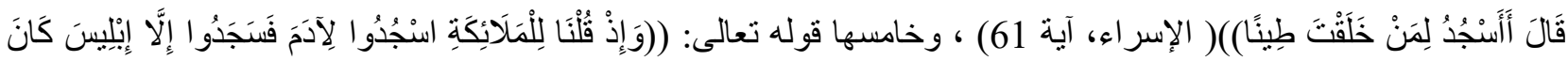




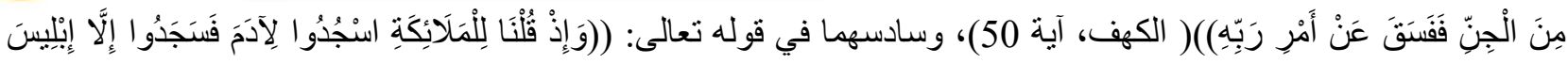
أَبَى))( طه، آية 116)، و آخر ما وقفنا عليه من آيات في يقينية تأثر نص الثـاعر المتقدم فيها هي الآيات المحكمات من سورة

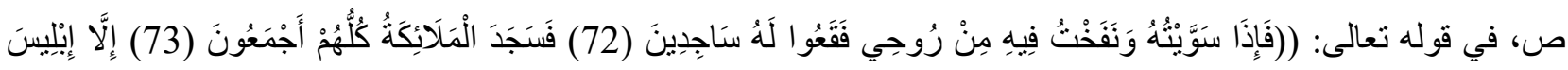

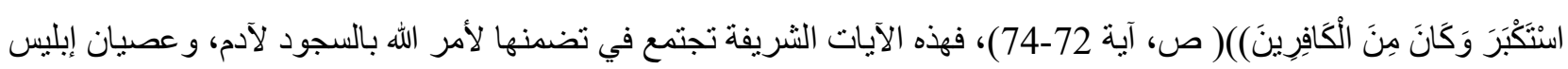
ذلك الأمر، وهو المعنى الذي وظفه الثاعر في المقطعين اللذينِ أشرنا لهما من نصها الشعري. ونختم استلهامات هذا النص الثعري المكثَّف، بإحالة المقطع الشعري الثاني من البيت الثالث (فحمل طوق اللعن في رقبته)

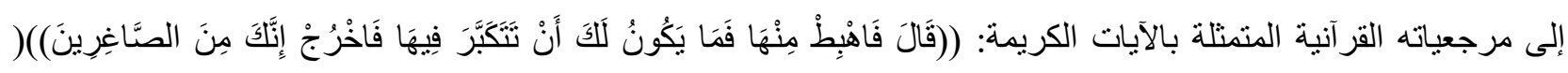

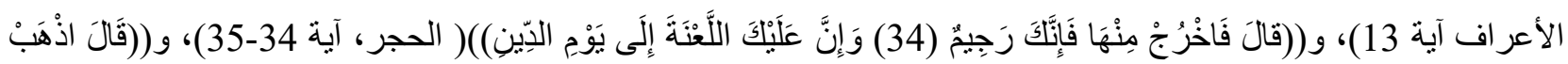

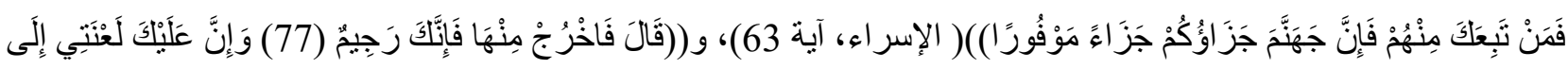

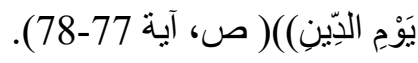

ونلحظ أن الآيات القر آنية المشار إليها في سورة الحجر و ص، كانت أقرب لنص الشاعر لفظا ومعنى، فقد أبرزت صورة (اللعن) لإبليس التي وظفها الثشاعر في نصده، مع وضوح الدلالة المعنوية لتلك الصورة في الآيات المشار إليها جميعا أيضا.

الخاتمة:

خلص البحث إلى نتائج كثيرة كان أهمها: 1-حاول البحث أن يلخص معايير المدرسة الفرنسية المقارنة التي قام البحث على معطياتها في الأدب المقارن، فأوجز معاييرها، فذكر أنها قامت على معيار التأثر والتأثير والمعيار اللغوي الجغرافي، ومعيار الصلة و الوثيقة، ومعيار مادية التأثثر.

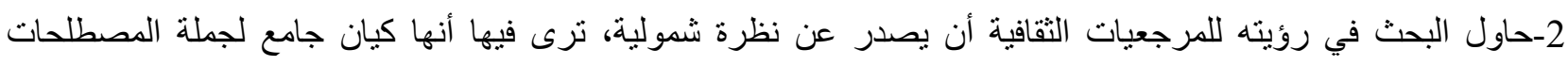

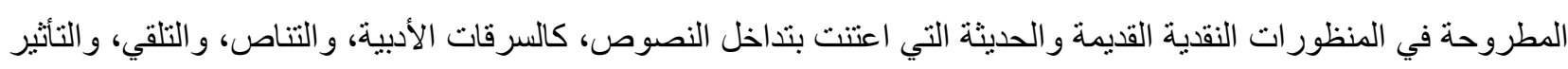
و التأثر ، و غير ها.

3-أصَّل البحث إلى فكرة تصدر عن تصور خاص بالدراسات المقارنة، تقوم على اشتراط خارجية المرجعية الثقافية لغويا وجغر افيا، بمعنى أن العينة المتأثرة تقع خارج منطقة العينة المتأثرة، وخارج إطار تو اصلها اللساني الجمعي.

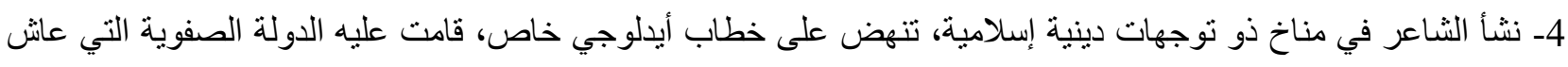
في ظلاها، وأنتج رؤية عقائدية صادرة عن مدرسة أهل البيت الكرام عليهم السلام، وجَّهت شعرية الخطاب عند الثاعر، فكان خطابه متداخلا في النص القر آني المقد تداخل إبداع و إعادة إنتاج، في ضوء رؤية مدرسة أهل البيت الكرام التفسيرية، سواء في المرجعية المباشرة، أو في المرجعية غير المباشرة. 5- حاول الثاعر من خلال موسوعيته التي اسنطالت على جزئيات الموروث العقائدي الذي تبناه، إعادة توجيه النص القرآني بحسب الخطاب المؤدلج المُتبنى، والصادر عن أئمة أهل البيت عليهم السلام في تفسير هم للقرآن الكريم، فهو يستدعي النص إنص القر آني ليجعله دليلا على خصوصية روايات أهل البيت وصدقها، ويجعل نصه ملائما لذائقة المتلقي التائق لهكذا توجيه.

المصادر والمراجع القرآن الكريم 
- - - آفاق الأدب المقارن عربيا وعالميا، حسام الخطيب، دار الفكر- دار الفكر المعاصر، دمثق- بيروت،

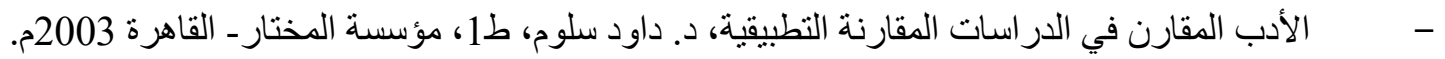
الأدب المقارن، ماريوس فرنسو ا غوبار، نر د. هنري زغيب، ط2، منشوران عويدات- بيروت 1988م.

الأدب المقارن، محمد غنيمي هلال، نهضة مصر للطباعة و النشر والتوزيعـ القاهرة، طو، 2008م. الأدب المقارن ، مقدمة نقدية ، سوزان باسنيت، ترجمة أميرة حسن نويرة، المجلس الأعلى للثقافةـ الهيئة العامة لثؤون المطابع الأميرية، 1999م.

إيران وعلاقاتها الخارجية في العصر الصفوي 906- 15248/ 1500-1736، نصر الله فلسفي، نرجمة محمد فتحي يوسف الريس، دار الثقافة للطباعة والنشر - القاهرة، 1989م.

تشالديران، سليم الأول العثماني و إسماعيل الصفوي، د شوقي أبو خليل، دار الفكر ـ دمشق، 2005م. تفسير الإمام العسكري عليه، المنسوب إلى الإمام العسكري عليه السلام تـ260ه، تحقيق مدرسة الإمام المهدي عليه السلام، مدرسة الإمام المهذي عليه السلام - قم المقدة، ط1، 1409/ 1989م.

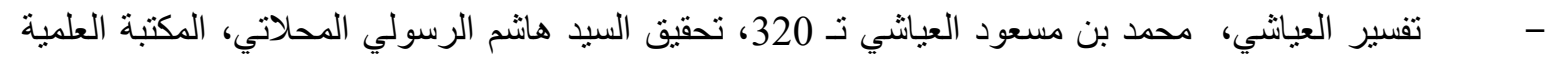
الإسلامية - طهر ان، د. ت.

تهذيب الأحكام، الثيخ الطوسي تـ460ه، تحقيق وتعليق: السيد حسن الموسوي الخرسان، دار الكتب الإسلامية - طهر ان، ط4، 1365 ش/ 1987م.

در اسات في الأدب المسرحي و الأدب المقارن، محمد زكي العشماوي، دار لشروق الأولىـ القاهرة، 1414ها 1994م. در اسات في الأدب المقارن، بديع محمد جمعة، دار النهضة العربية للطباعة والنشر - بيروت، ط2، 1980م. الثامل قاموس مصطلحات العلوم الاجتماعية، مصلح الصالح، دار عالم الكتب، الرياض، ط1، 1999م. الصحاح تاج اللغة وصحاح العربية، أبو نصر إسماعيل بن حماد الجوهري الفارابي تـ 393هـ، تحقيق أحمد عبد الغفور عطار، دار العلم للملايين - بيروت، ط4، 1407 هـ- 1987 م. الظو اهر الأدبية في العصر الصفوي، محمد السعيد عبد المؤمن، مكتبة الأنجلو المصريةـ القاهرة، 1398ه/ 1978م. عمدة عيون صحاح الأخبار في مناقب إمام الأبرار، ابن البطريق تـ600ه، مؤسسة النشر الإسلامي التابعة لجماعة المدرسين- قم، 1987/01407م. العين، أبو عبد الرحمن الخليل بن أحمد بن عمرو بن تميم الفراهيدي البصري تـ170هـ، تحقيق د مهدي المخزومي، د إير اهيم السامر ائي، دار ومكتبة الهلال، د. ت. 
الكافي، الثيخ الكليني تـ 329ه، تحقيق: علي أكبر الغفاري، دار الكتب الإسلامية - طهران، ط5، 1363ش/

الكتاب، عمرو بن عثمان بن قنبر الحارثي بالولاء، أبو بشر، الملقب سيبويه تـ180هـ، تحقيق عبد السلام محمد هارون مكتبة الخانجي- القاهرة، ط3، 1408 هـ/ 1988 م.

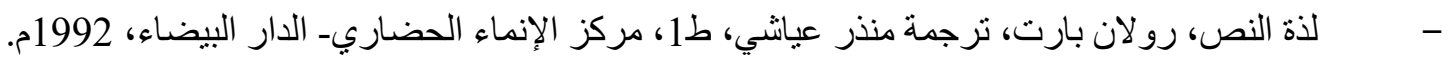
- - معجم المصطلحات العربية في اللغة والأدب، مجدي وهبة و كامل المهند، مكتبة لبنان- بيروت، ط2، 1984

من شعر اء إيران الكبار وحشي البافقي، د. أحمد الخولي، مكتبة الأنجلو المصرية_القاهرة، ط1، 1978م. الهجرة العاملية إلى إيران في العصر الصفوي، أسبابها التارخية ونتائجها الداخلية، جعفر المهاجر، دار الروضة للطباعة و النشر و التوزيع- بيروت، ط1، 1410/ 1989 1989م.

الشعائر الحسينية في العصر الصفوي، عرض ونوصيف، د.الثيخ حيدر خماس الساعدي، الإصلاح الحسيني (مجلة)، العدد13، السنة الرابعة، 1437/016/ 2016م. - - المرجعيات الثقافية بين المفهوم والتوظيف، د حكيمة سبيعي، و هولي بوزياني، خولة، مجلة البحوث و الدراسات(مجلة)، المجلد (16)، العدد2، صيف 2019م. 